\title{
Toward a Fossil Free Future with HYBRIT: Development of Iron and Steelmaking Technology in Sweden and Finland
}

\author{
Martin Pei ${ }^{1, *}$, Markus Petäjäniemi ${ }^{2}$, Andreas Regnell ${ }^{3}$ and Olle Wijk ${ }^{4}$ \\ SSAB AB, 10121 Stockholm, Sweden \\ 2 LKAB (Luossavaara-Kiirunavaara Aktiebolag), Box 952, 97128 Luleå, Sweden; \\ markus.petajaniemi@lkab.com \\ 3 Vattenfall AB, 16992 Stockholm, Sweden; andreas.regnell@vattenfall.com \\ 4 Hybrit Development AB, 10724 Stockholm, Sweden; olle.wijk@hybrit.se \\ * Correspondence: martin.pei@ssab.com; Tel.: +46-8454-5780
}

Received: 10 June 2020; Accepted: 13 July 2020; Published: 18 July 2020

\begin{abstract}
The Swedish and Finnish steel industry has a world-leading position in terms of efficient blast furnace operations with low $\mathrm{CO}_{2}$ emissions. This is a result of a successful development work carried out in the 1980s at LKAB (Luossavaara-Kiirunavaara Aktiebolag, mining company) and SSAB (steel company) followed by the closing of sinter plants and transition to $100 \%$ pellet operation at all of SSAB's five blast furnaces. However, to further reduce $\mathrm{CO}_{2}$ emission in iron production, a new breakthrough technology is necessary. In 2016, SSAB teamed up with LKAB and Vattenfall AB (energy company) and launched a project aimed at investigating the feasibility of a hydrogen-based sponge iron production process with fossil-free electricity as the primary energy source: HYBRIT (Hydrogen Breakthrough Ironmaking Technology). A prefeasibility study was carried out in 2017, which concluded that the proposed process route is technically feasible and economically attractive for conditions in northern Sweden/Finland. A decision was made in February 2018 to build a pilot plant, and construction started in June 2018, with completion of the plant planned in summer 2020 followed by experimental campaigns the following years. Parallel with the pilot plant activities, a four-year research program was launched from the autumn of 2016 involving several research institutes and universities in Sweden to build knowledge and competence in several subject areas.
\end{abstract}

Keywords: fossil-free steel; hydrogen direct-reduced iron $\left(\mathrm{H}_{2} \mathrm{DRI}\right)$; melting of $\mathrm{H}_{2} \mathrm{DRI}$ in EAF (Electric Arc Furnace); hydrogen production by water electrolysis; hydrogen storage; grid balancing; renewable electricity

\section{Introduction}

The three Swedish companies SSAB (steel company), LKAB (mining company), and Vattenfall $\mathrm{AB}$ (energy company) aim at creating the first fossil-free value chain from mining to finished steel. The initiative is based on the importance of steel as a material for the development of the modern society and the big impact of today's production lines on the emission of fossil-based carbon dioxide.

Steel is $100 \%$ recyclable and has eternal applications including transportation, energy, drinking water, food production, buildings, and infrastructure. Volume wise, steel is the dominating material, and the global steel demand is estimated to increase from 1800 in 2018 to 2500 million tons in 2050 [1].

In the Paris agreement from 2015 [2], countries of the world agreed on a new global climate strategy that provides the framework for future long-term climate efforts. The global annual $\mathrm{CO}_{2}$ emission from the steel industry is currently around 2.8 billion ton corresponding to $7 \%$ of the global total $\mathrm{CO}_{2}$ emission. As illustrated in Figure 1, to reach the goals of global temperature increases of 
maximum $2{ }^{\circ} \mathrm{C}$ defined in the Paris agreement, the emission from the steel industry should be decreased to a level of 400-600 million ton per year in 2050 at the same time as the forecasted production volumes will increase.

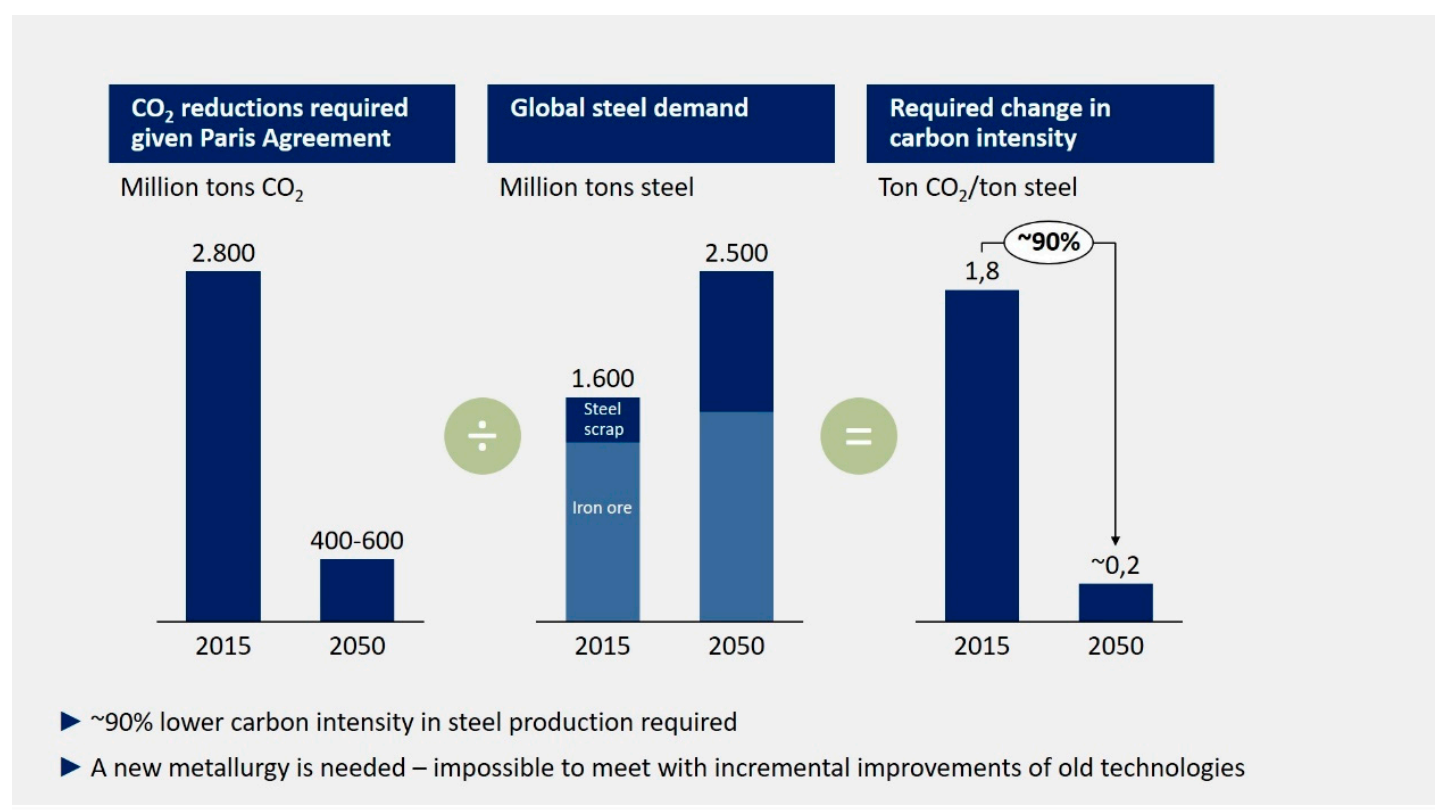

Figure 1. Global steel demand and required decrease of $\mathrm{CO}_{2}$ emissions in 2050, data from [1].

In Sweden, following the Paris agreement, the parliament has adopted a climate law with the target that Sweden should have no net emissions of greenhouse gases by the year 2045. Furthermore, a long-term agreement was reached between the majorities of the left- and right-wing political parties, where it was confirmed that the Swedish electricity production should aim at $100 \%$ renewable energy sources by the year 2040 .

In Finland, a climate plan was presented in 2019 with the target that Finland shall be carbon-neutral by 2035 with the ambition to be "the first fossil-free welfare society".

SSAB has at its Nordic production units a total annual $\mathrm{CO}_{2}$ emission of around 9 million tons, as shown in Figure 2, of which 5 million tons are emitted in Sweden corresponding to $10 \%$ of the total emissions in the country. The corresponding figures for the Finnish production are 4 million tons and $7 \%$ respectively of total Finnish emission.

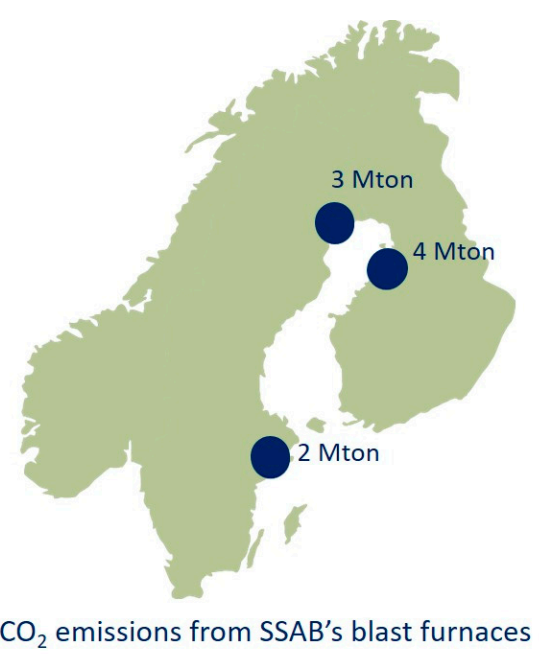

Figure 2. $\mathrm{CO}_{2}$ emissions in SSAB's (steel company's) steel works with BF-BOF (Blast Furnace-Basic Oxygen Furnace) in Sweden and Finland. 
In the present paper, the HYBRIT (Hydrogen Breakthrough Ironmaking Technology) project, a Swedish initiative between the three companies SSAB, LKAB, and Vattenfall AB, is described.

\section{The Blast Furnace Route}

Scandinavia has a very long history in iron and steelmaking based on abundant natural resources in forests, hydro-power, and high-grade iron ores. Globally as well as in Scandinavia, the steel industry in periods has met big challenges that have resulted in changes of the industrial landscape, as shown in Figure 3 [3].

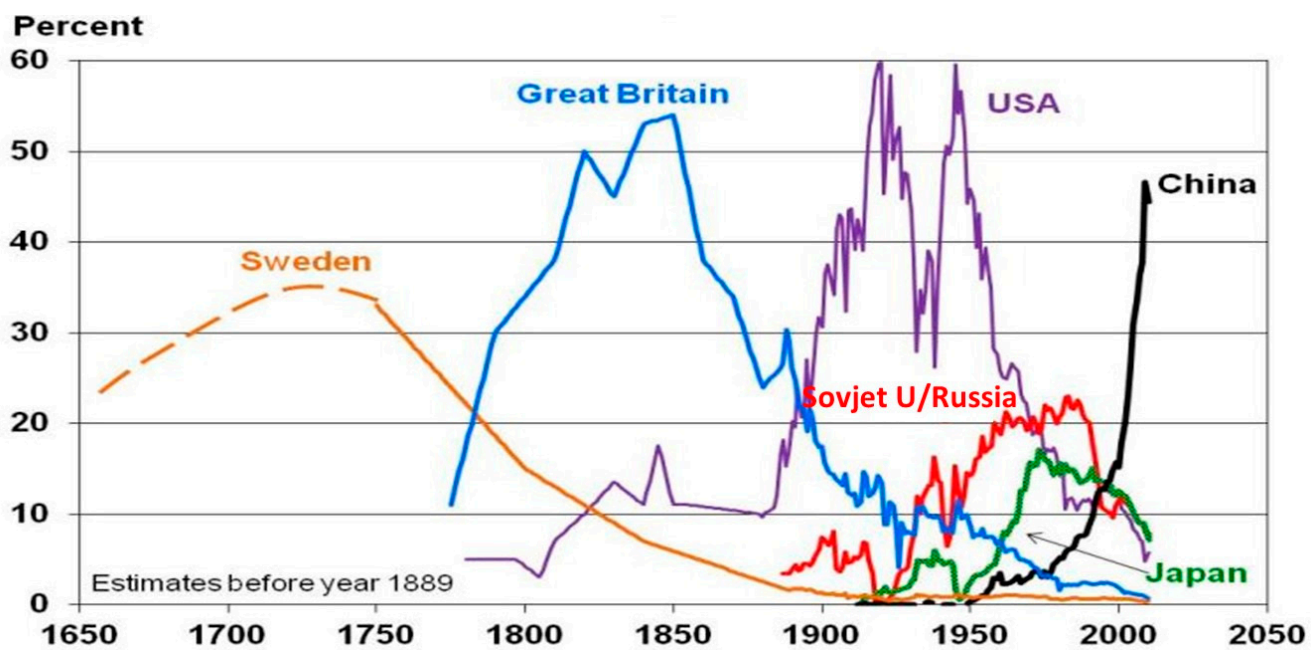

Figure 3. World steel production, historical data from [3].

In the beginning of the 18th century, Sweden dominated global steel production. During a few decades in the late 1700s and the beginning of the 1800s, Sweden's share of the global production was around $35 \%$. This leading position changed rapidly to below $10 \%$ when expensive charcoal could be replaced by low-cost natural coal to produce commodity products. Many of the small iron and steelworks went into bankruptcy. A similar development could be seen in the second half of the 19th century. Around 1860, Sweden had 225 blast furnaces in operation. The introduction of processes such as Bessemer, Thomas, and Martin replaced different kinds of small-scale steelmaking processes, resulting in the closing of many iron and steelworks.

During the 20th century, several efforts were made in Sweden to replace the blast furnace. The common aim of these developments was to decrease or eliminate the need for the agglomeration of iron ore fines and to avoid dependence on coking coal. In some cases, the aim was also to find effective solutions to process the Swedish high-phosphorus iron ores. These initiatives peaked in the 1970s when several processes [4] were under development such as INRED, ELRED, Plasmasmelt, and the KTH-converter smelting reduction process. All of these were run on a pilot scale, and the $\mathrm{KTH}$-converter process was also used for coal gasification in a converter combined with iron production.

Extensive research was performed around 1980 in a Swedish national program-Steel Production from High-phosphorus Iron Ore [5], where the focus was on the LKAB iron ores and the challenges facing the steel industry. The production process from mining to the production of the finished product was thoroughly studied in cooperation between academia and the industry. In this program, which was performed both on a national and international level, knowledge and competence was developed, which contributed to the competitive iron and steelmaking technology still used in Sweden.

Today, the Swedish high-phosphorus iron ores are upgraded to pellets with very low phosphorus content, which together with the development of both pellet properties and blast furnace technology have given world-leading results and low emissions. These achievements are based on a long-term close cooperation between LKAB and SSAB. 
With an annual Nordic iron ore-based steel production of around 6 million tons, the focus today is on niche products for special purposes and high customer values. This strategy has made the industry competitive despite, from a global perspective, limited production volume. In addition to a very strong focus on product development both regarding iron ore products and finished products, there has been extensive activities regarding process development to improve productivity and decrease fuel consumption in the different production steps. The most significant development step is the joint development effort at LKAB and SSAB in the beginning of the 1980s with the self-fluxing olivine pellet, which resulted in the significant efficiency improvement of the combined LKAB-SSAB production value chain from iron ore to crude steel.

In Figure 4, the development of fuel consumption at LKAB for iron-ore agglomeration from 1960 until today is given in oil equivalents. The decrease is from $50 \mathrm{~L}$ per ton in 1960 to $8 \mathrm{~L}$ per ton pellet in 2013. The $\mathrm{CO}_{2}$ emissions have decreased from $192 \mathrm{~kg} /$ ton product in 1960 to $31 \mathrm{~kg}$ in 2013. The step from shaft furnace to grate kiln resulted in a significant improvement, and new generations of pelletizing processes during the following decades resulted in further improvements, as shown in the figure below. To further decrease/eliminate these emissions, special actions must be taken.

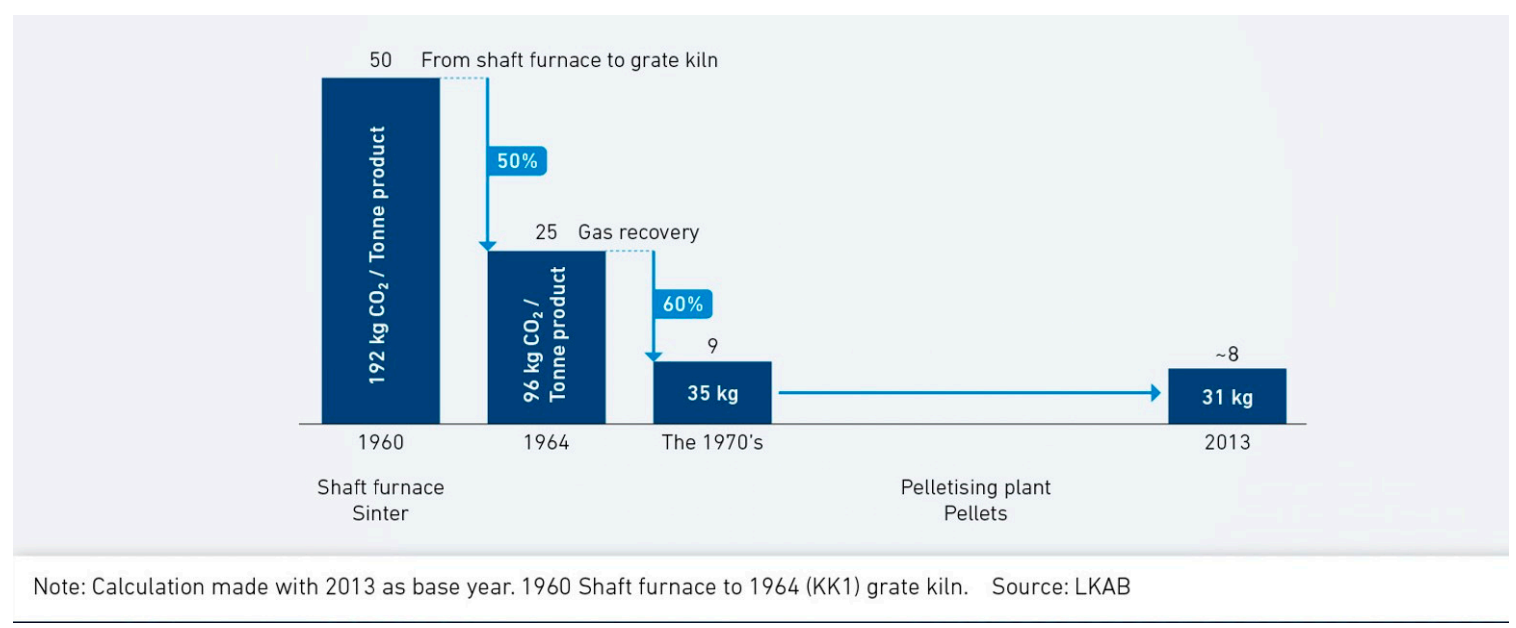

Figure 4. Agglomeration of iron ore development in fuel consumption (oil equivalents per ton of product) and $\mathrm{CO}_{2}$ emissions since 1960 .

The modern blast furnace is a very effective and advanced unit with sophisticated process control systems. SSAB, which today has a world-leading position in blast furnace fuel rate, has in total five blast furnaces in Sweden and Finland. The blast furnaces are all run with $100 \%$ self-fluxing iron ore pellets, and pulverized coal injection (PCI) is performed. Figure 5 gives the development during the last decades at the SSAB blast furnace in Luleå, Sweden. The fuel rate today is on average 450-460 kg per ton of hot metal, of which around $150 \mathrm{~kg}$ comes from PCI. The slag volume is very low: around $120 \mathrm{~kg}$ per ton of hot metal. 


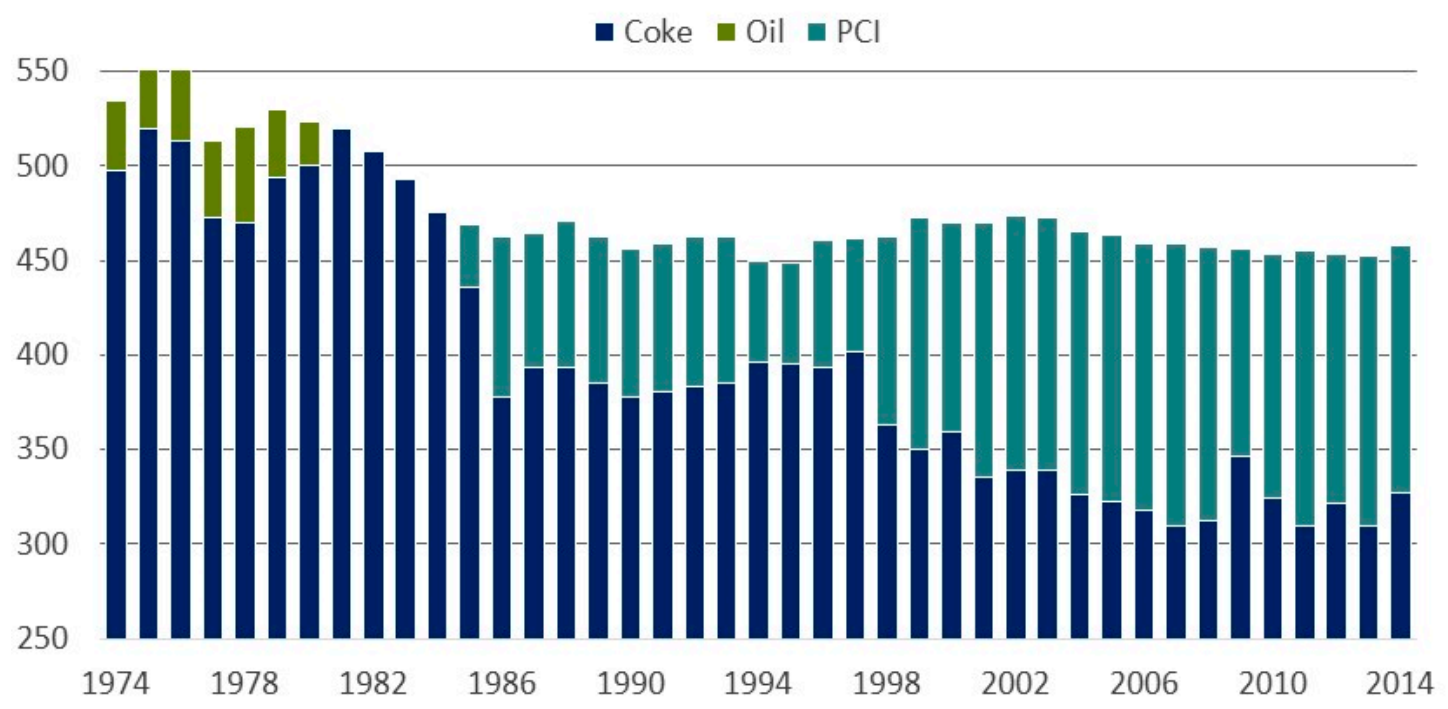

Figure 5. Development of the fuel rate in the blast furnace at SSAB in Luleå, Sweden.

Several initiatives [6] have been taken globally during the last decades to decrease $\mathrm{CO}_{2}$ emissions and to further develop the blast furnace and to utilize the process as a flexible tool for different fuels. Examples are replacing PCI with bio-coal or recycled plastic materials, top gas recycling, the plasma heating of blast, the injection of hydrogen from coke oven gas or hydrogen produced with electricity, the further increased injection of oxygen, etc. There are also ongoing investigations, including Carbon Capture and Storage (CCS) for the storage of produced $\mathrm{CO}_{2}$ and utilization of the produced $\mathrm{CO}_{2}$ as a raw material to produce different chemicals (CCU). It is obvious that several initiatives are needed to solve the very demanding situation for the industry.

Pilot plant experiments within the European ULCOS (Ultra-Low Carbon dioxide (CO2) Steelmaking) project [7] carried out at LKAB's experimental blast furnace at the research institute SWERIM in Luleå Sweden showed that when modifying the blast furnace with top gas recirculation combined with CCS, a reduction of approximately $50 \% \mathrm{CO}_{2}$ emission is achievable.

Within SSAB's Raahe unit in Finland, full-scale experiments were performed during 2019 aiming at replacing fossil coal with bio-coal [8]. It was shown that replacing $5-20 \%$ of the PCI coal with bio-coal is technically feasible and would, with the highest rates of bio-coal injection in the blast furnace in question, give a $\mathrm{CO}_{2}$ emission reduction of 200,000 ton/year. The limiting factor is the availability of bio-coal.

\section{The HYBRIT Initiative}

The use of hydrogen produced by water electrolysis using fossil-free electricity to reduce iron ore pellets in a shaft furnace was the main alternative chosen for the HYBRIT initiative. A conversion to a fossil-free value chain from the mine to the finished steel includes many issues to be developed where also local market and geographical conditions must be taken into consideration. Sweden has a unique situation with overcapacity in electrical power in the northern part of the country, vicinity to iron ore mines, good access of biomass and steelworks, and a strong network between industry, research institutes, and universities. Three key areas important for the HYBRIT initiative should be mentioned:

Hydrogen reduction of iron ore has been studied for many decades. There were pioneering investigations in Sweden by Wiberg [9] and Edström [10] already in the 1950s, which have been followed by a number of investigations [11-13] describing the kinetics of the process as well as the reactivity of the produced product. The first commercial scale hydrogen direct reduction of iron ore $\left(\mathrm{H}_{2} \mathrm{DRI}\right)$ plant based on fluidized bed technology, Circored [14], was built in 1998 by Cliffs and Associates Ltd. at Point Lisas Industrial Complex in Trinidad in 1998. The plant had a designed capacity 
of 500,000 tons per annum of Hot Briquetted Iron (HBI). The plant did not succeed commercially and was closed down in 2016.

The overall reaction for the reduction of hematite with hydrogen is:

$$
\mathrm{Fe}_{2} \mathrm{O}_{3}+3 \mathrm{H}_{2}=2 \mathrm{Fe}+3 \mathrm{H}_{2} \mathrm{O}
$$

Reaction (1) is endothermic with a heat of reaction, $\Delta \mathrm{H}_{298}=95.8 \mathrm{~kJ} / \mathrm{mol}$ [15], which is negative for the energy balance of the process and demands an addition of energy with the injected reduction gas/gas mixture. The focus in developing the production line is optimization based on the reduction temperature, kinetics of the reaction, pellet composition, and technology for the preheating of the reduction gas.

Hydrogen storage will give benefits from an electricity sourcing/pricing perspective, but it is not as such critical for the process concept. Today, the most cost-efficient alternative for hydrogen storage is underground pressurized storing, where there the most cost-efficient alternatives are storing in underground salt formations, which today is the only technology for hydrogen storage tested on an industrial scale [16]. Other solutions attracting a lot of interest nowadays include utilizing natural gas pipelines and conversion to ammonia or hydrocarbons as intermediate hydrogen storage. Initial evaluation of the Lined Rock Cavern (LRC) technology used currently in Sweden for natural gas is considered to be promising also [17-19]. Other alternative methods for hydrogen storage under development are storage in metal hydrides and in porous materials.

Since the electric arc furnaces (EAFs) for the melting of steel scrap were introduced on an industrial scale in the 1920s, the technology has developed tremendously. For many years, the EAFs were used for both melting and refining, resulting in a low productivity. Today's furnaces, based on ultra-high power, water cooled panels, and foaming slag practices, are used as melting units, and they are combined with refining in the ladle before casting. Tap to tap times, the time period between sequential tappings of the furnace into the casting ladle, have developed from being several hours to typically below $60 \mathrm{~min}$. The introduction of a foaming slag practice in many steel shops in the 1970s has been crucial for this development. The injection of coal powder and oxygen creates a formation of $\mathrm{CO} / \mathrm{CO}_{2}$ which combined with a proper slag composition results in a foaming slag that protects the furnace walls from the electric arcs. By doing so, it is possible to have a high-power input also at the end of the melting process when the melt temperature is increased before tapping.

The worldwide production of direct reduced iron based on natural gas was 104 million tons in 2018 [20], and the melting in EAF shops is a well-established technology. A melting practice for increased productivity was developed already in the 1970s [5,21-23] and includes typically continuous feeding of DRI and the application of a foaming slag practice. Commercial direct reduced iron contains normally $1-2 \%$ carbon, which is beneficial for the melting process and for obtaining a foaming slag.

A hydrogen-based reduction process results in a low carbon iron product, indicating that a fossil-free carbon source is needed to obtain a final commercial attractive product for the steelmaking step.

On 4 April 2016, the three Swedish companies—SSAB, LKAB, and Vattenfall AB-launched a project aimed at investigating the feasibility of a hydrogen-based sponge iron production process, with $\mathrm{CO}_{2}$ emission-free electricity as the primary energy source-HYBRIT (Hydrogen Breakthrough Ironmaking Technology). A joint venture company was formed, HYBRIT Development AB, with the three companies being owners. This gives full access to top competence in the entire value chain from energy production, mining, ore beneficiation and pellet production, direct reduction, melting, and the production of crude steel.

A prefeasibility study on hydrogen-based direct reduction was carried out in 2017. The study concluded that the proposed process route is technically feasible and, in view of future trends on costs for $\mathrm{CO}_{2}$ emissions and electricity, it is also economically attractive for conditions in northern Sweden/Finland. 
The principle layout of the HYBRIT production process and as a comparison the blast furnace production process is given schematically in Figure 6. The main characteristics are the following:

- Non fossil fuels are used in pellet production

- Hydrogen is produced with electrolysis using fossil-free electricity

- Storage of hydrogen in a specially designed unit is used as a buffer to the grid

- A shaft furnace is used for iron ore reduction

- Tailor-made pellets are used as iron ore feed

- The reduction gas/gas mixture is preheated before injection into the shaft

- The product can either be DRI or HBI free of carbon or carburized

- The DRI/HBI is melted together with recycled scrap in an electric arc furnace

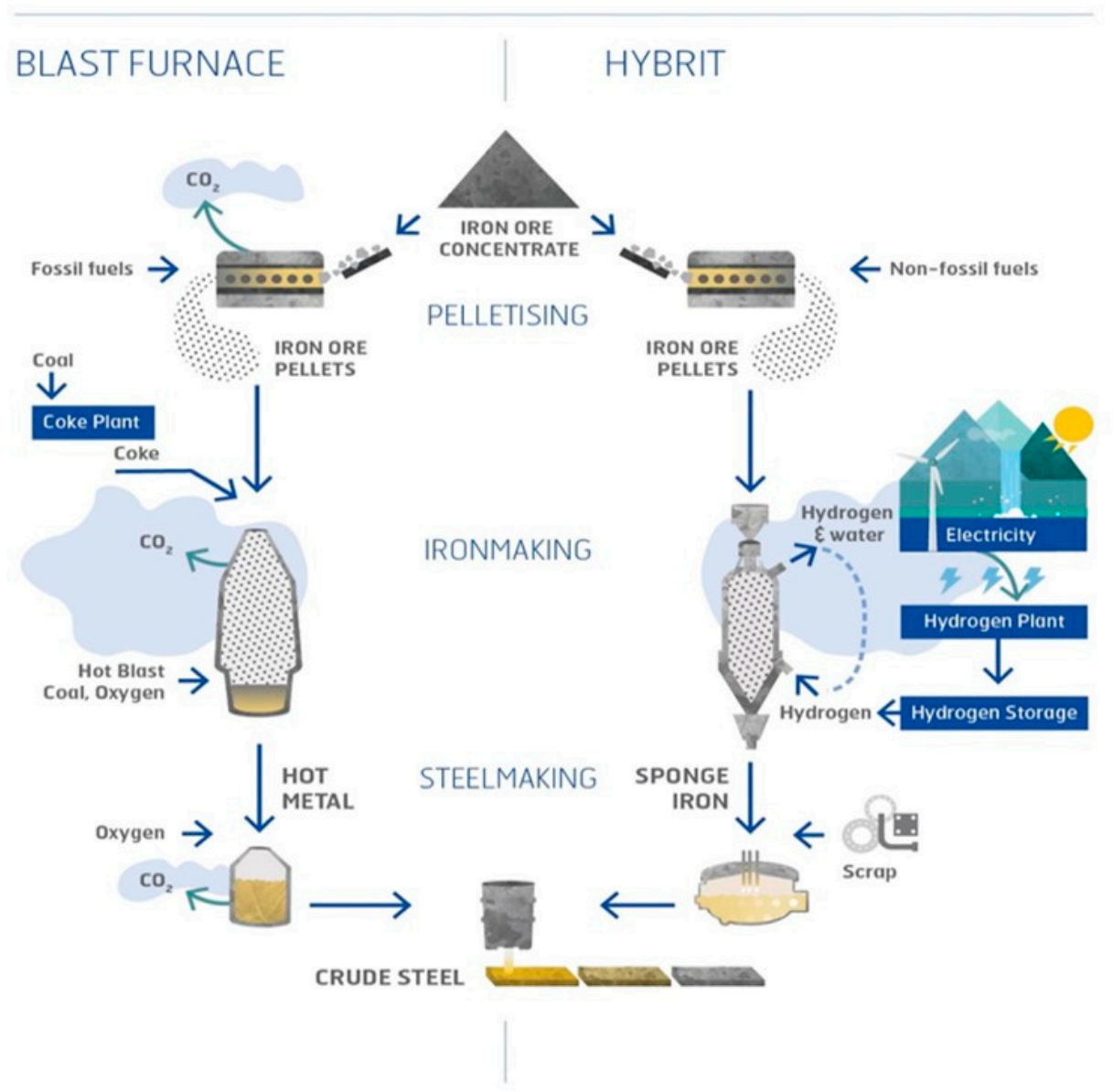

Figure 6. The blast furnace route and HYBRIT-Hydrogen Breakthrough Ironmaking Technology.

A comparison of some consumption figures between the blast furnace route and the HYBRIT route are given in Figure 7 [24]. In the HYBRIT initiative, fossil-free energy sources are used in the whole production line from the pellet production to the produced crude steel. The only direct fossil carbon load comes from the consumption of graphite electrodes and from carbon added in the EAF melt shop. In the example, the fossil $\mathrm{CO}_{2}$ emission decreases from $1600 \mathrm{~kg} / \mathrm{ton}$ of crude steel to $25 \mathrm{~kg} / \mathrm{ton}$. In this example, in northern Sweden, the availability of renewable electricity (such as hydropower and wind power) together with good access to biomass used in the HYBRIT route replaces the fossil fuel used in the Blast Furnace route, thus eliminating most of the fossil $\mathrm{CO}_{2}$ emissions. 


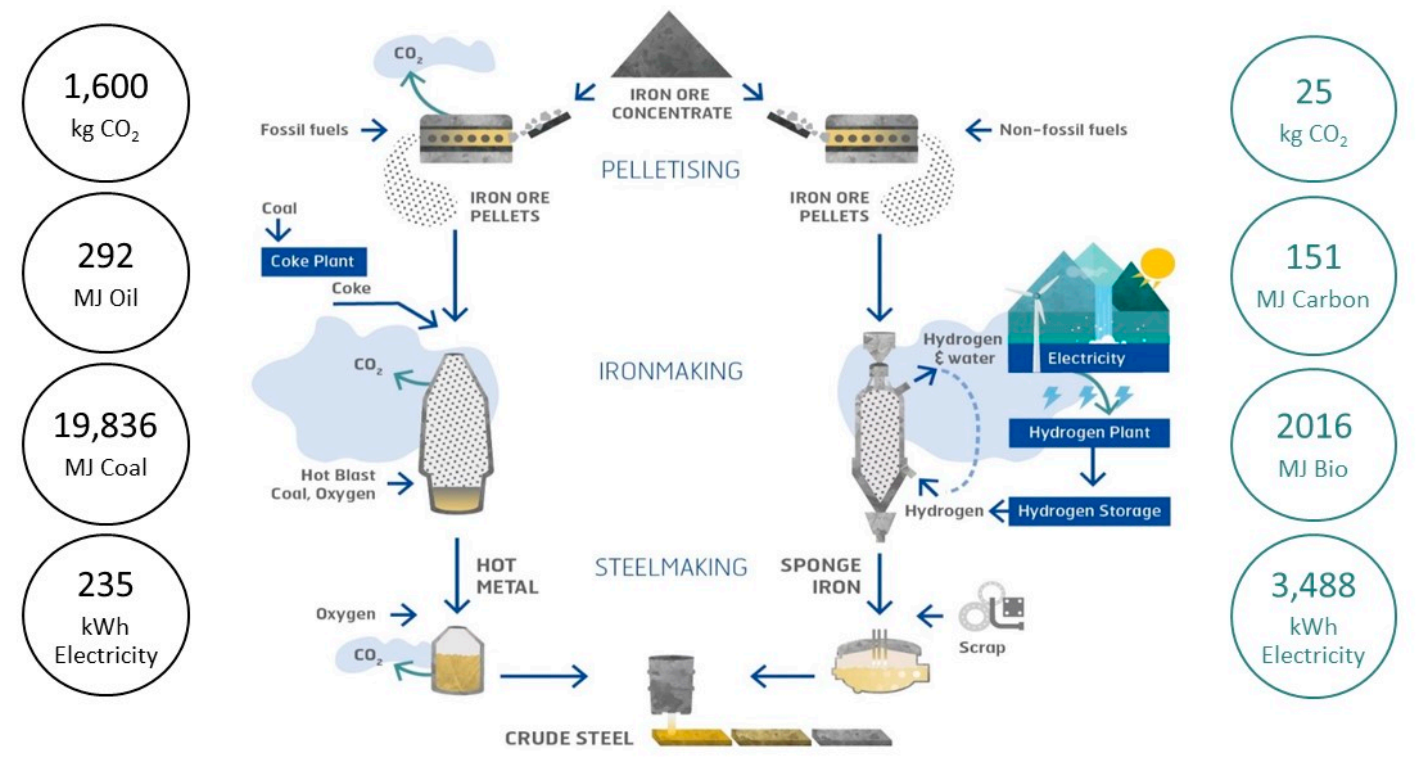

Figure 7. Comparison of some emission and consumption figures for the SSAB blast furnace route and the HYBRIT concept, data from [24].

A critical parameter for the production economy is the cost of electricity. By utilizing fossil-free energy sources such as wind power and optimizing the production time in the electrolysis and the size of the hydrogen storage, simulations have shown that the price for electricity can be lowered by $6-7 \%$.

A production cost comparison, January 2018, based on greenfield units for Swedish/Finnish conditions resulted in increased production costs of 20-30\% compared with the blast furnace route. In the future, the HYBRIT concept is estimated to be more attractive due to higher costs for the emission of $\mathrm{CO}_{2}$ and lower renewable electricity costs. The industry will also prevent being dependent on the limited resources of coking coal. It was also concluded that a scale up to pilot and demo plants is critical for the development.

A decision was made in February 2018 to build a pilot plant with a capacity of 1 ton/h at the SSAB site in Luleå, Sweden, and the construction started in June 2018. Completion of the plant is planned for the summer 2020 followed by experimental campaigns during the coming years, as shown in Figure 8 .

The plant is designed for using hydrogen as a reduction gas but will have flexibility where other gases such as biogas can be used also.

Since 2016, the HYBRIT project has expanded, and four different pilot projects are today included in the initiative, as shown in Figure 9. Since 2016, a four-year research program involving several research institutes and universities in Sweden has been run also to build competence and knowledge in different areas, such as the fundamental reduction mechanisms of hydrogen direct reduction of iron ore $\left(\mathrm{H}_{2} \mathrm{DRI}\right)$, the melting behavior of $\mathrm{H}_{2} \mathrm{DRI}$, new heating and sintering techniques without fossil fuel, hydrogen production and storage techniques, and electricity grid balancing, as well as research in policy aspects as an enabler for the steel industries' transition to carbon neutrality. Around 100 engineers and researchers from industry, research institutes, and academia are today active in the HYBRIT initiative. 


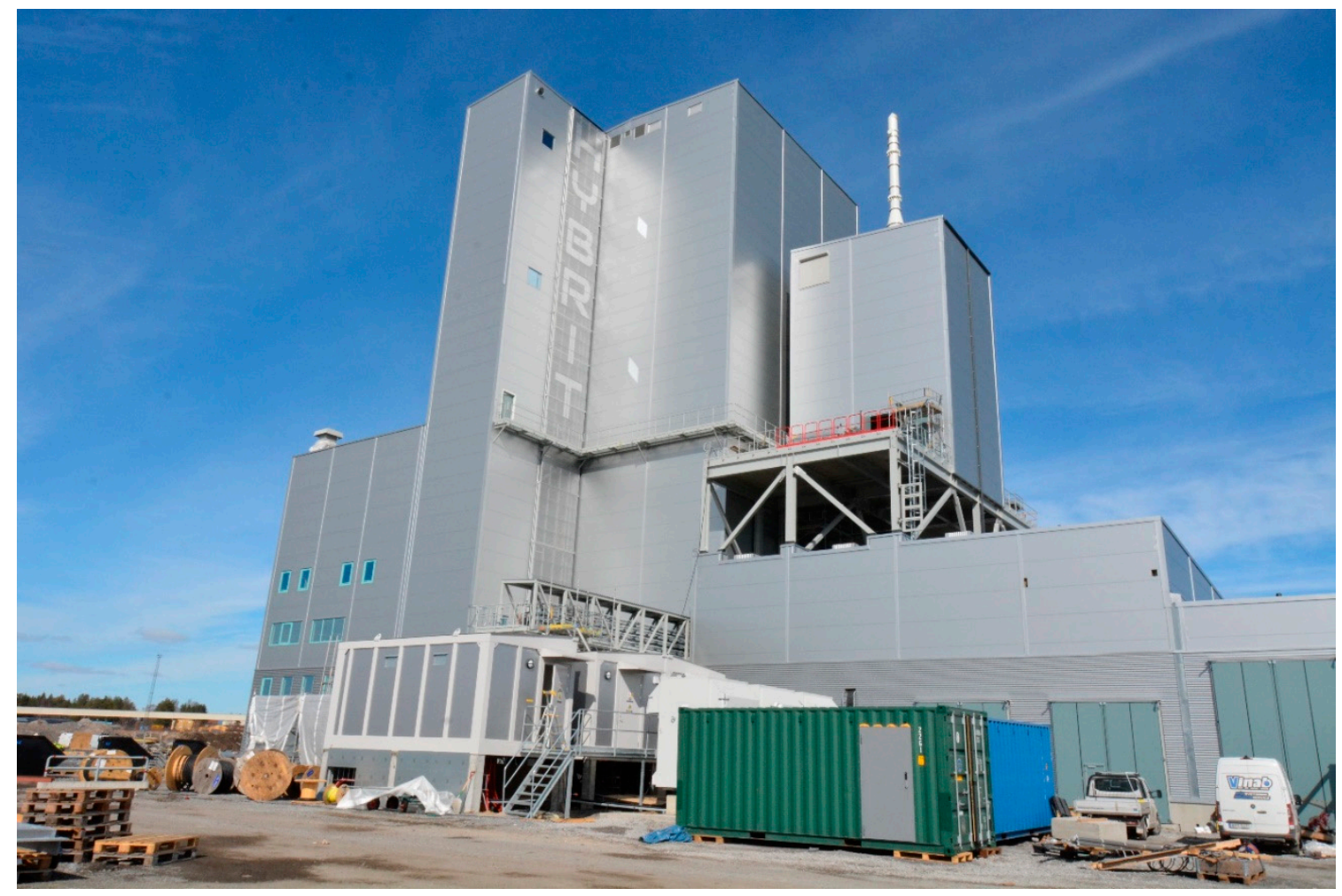

Figure 8. The pilot plant in Luleå, Sweden, under construction.

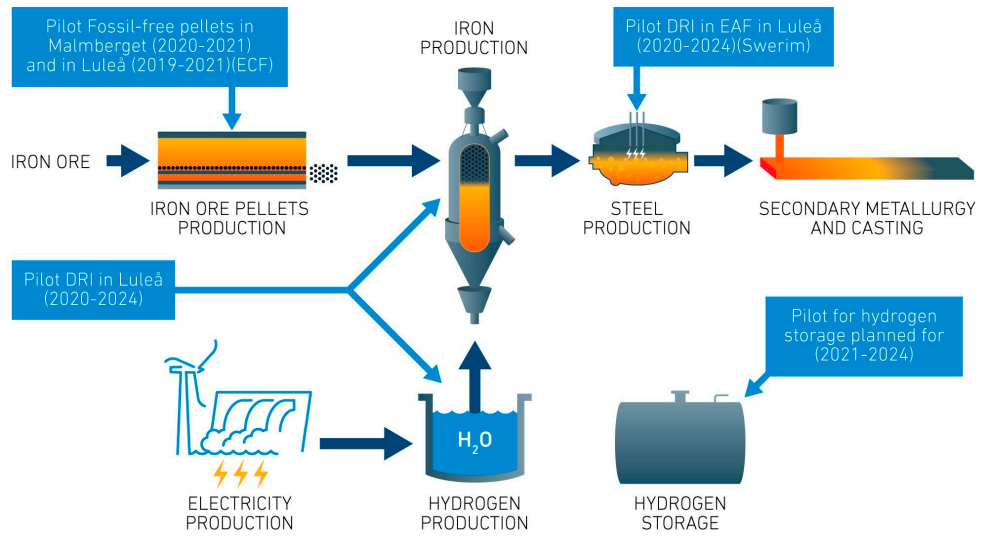

Figure 9. Pilot projects included in the HYBRIT initiative: Pilot for fossil-free pellets, pilot for hydrogen storage, direct reduction of iron ore (DRI) pilot, and electric arc furnace (EAF) pilot.

A roadmap for the transformation of the production line from pellet production to crude steel is given in Figure 10. During 2019, a decision was made to start the planning for the first demonstration plant for HYBRIT to be put into production in 2025, which is the same year that SSAB's Oxelösund plant is planned to be converted from the blast furnace route to the electric arc furnace route, to enable SSAB to be the first steel company in the world providing fossil-free steel to the market. 


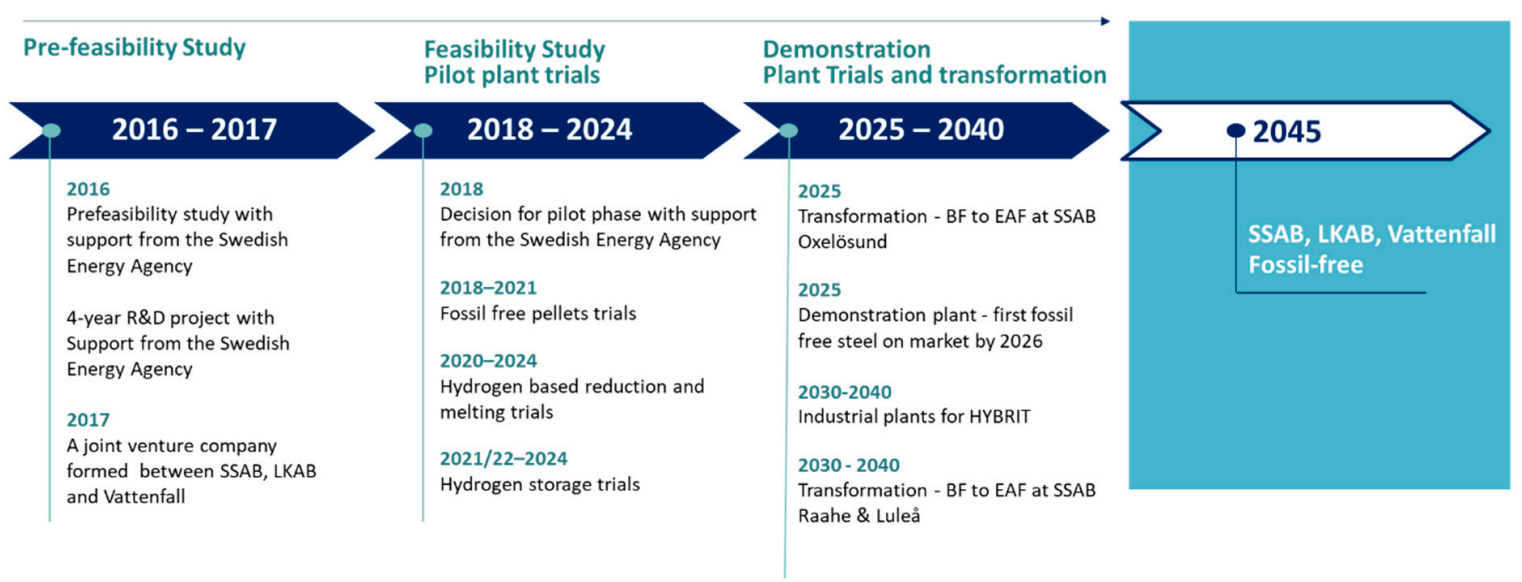

Figure 10. Roadmap to replace coal/coke-based blast furnace operations with fossil-free electricity in Sweden and Finland.

\section{Final Comments}

The climate change has put a lot of focus on global $\mathrm{CO}_{2}$ emissions. All sectors of the society including energy, agriculture, transportation, construction, and industry are affected by the situation. Regarding the steel industry, several initiatives are ongoing, which is very important depending on the technical risks and geographical differences regarding the availability of energy and raw materials.

In the present paper, which gives a general overview of the HYBRIT project, some findings and a future strategy are described. So far, the results look promising, and the very broad competence areas including energy supply and hydrogen production, mining, and the development of pellets for direct reduction and iron and steelmaking strengthens this belief. The planned pilot plant experiments will be critical for the scaling up of this technology.

Author Contributions: Conceptualization, M.P. (Martin Pei), M.P. (Markus Petäjäniemi), A.R. and O.W.; Data curation, M.P. (Martin Pei); Formal analysis, M.P. (Martin Pei) and O.W.; Funding acquisition, M.P. (Martin Pei), M.P. (Markus Petäjäniemi) and A.R.; Investigation, M.P. (Martin Pei) and O.W.; Methodology, M.P. (Martin Pei) and O.W.; Project administration, M.P. (Martin Pei) and O.W.; Resources, M.P. (Martin Pei), M.P. (Markus Petäjäniemi) and A.R.; Supervision, M.P. (Martin Pei) and O.W.; Validation, M.P. (Martin Pei) and O.W.; Visualization, M.P. (Martin Pei) and O.W.; Writing-original draft, M.P. (Martin Pei) and O.W.; Writing-review and editing, M.P. (Martin Pei), M.P. (Markus Petäjäniemi), A.R. and O.W. All authors have read and agreed to the published version of the manuscript.

Funding: The Swedish Energy Agency, through the Swedish Industrial Leap program, together with the three companies involved, have provided financial support to HYBRIT Development AB.

Conflicts of Interest: The authors declare no conflict of interest.

\section{References}

1. Material Economics. The Circular Economy-A Powerful Force for Climate Mitigation. Available online: https: //www.climate-kic.org/insights/the-circular-economy-a-powerful-force-for-climate-mitigation-2/ (accessed on 18 April 2019).

2. Paris Agreement. Agreement between 197 nations after negotiations in Paris within the United Nations Framework Convention on Climate Change; Paris Agreement: Paris, France, 2015.

3. Swedish Iron and Steel Makers Association; Jernkontoret: Stockholm, Sweden, 2019.

4. Edström, J.O. Råjärnsprocesser—Sveriges FoU-Behov; STU-Utredning nr 74: Stockholm, Sweden, 1977.

5. Edström, J.O. Stålframställning ur Fosforrik Järnmalm; STU Information 256: Stockholm, Sweden, 1981.

6. Roland Berger. The Future of Steelmaking-How the European Steel Industry Can Achieve Carbon Neutrality; Roland Berger GMBH: Munich, Germany, 2020.

7. Burström, E. ULCORED SP12, Concept for Minimized $\mathrm{CO}_{2}$ Emission, 4th ed.; ULCOS Seminar: Essen, Germany, 2008.

8. Lilja, J. SSAB Europe, Private Communication, 2019. 
9. Wiberg, M. Some new ways of producing Sponge Iron. Jernkontorets Ann. 1956, 142, 289-355.

10. Edström, J.O. The Mechanism of Reduction of Iron Oxides. J. Iron Steel Inst. 1953, 175, 289-304.

11. Tsay, Q.T.; Ray, W.H.; Szekely, J. The modelling of hematite reduction with hydrogen plus carbon monoxide mixtures. AlChE J. 1976, 22, 1064-1072. [CrossRef]

12. Wagner, D.; Devisme, O.; Patisson, F.; Ablitzer, D. A Laboratory Study of the Reduction of Iron Oxides by Hydrogen. In Proceedings of the Sohn International Symposium, San Diego, CA, USA, 27-31 August 2006.

13. Kazemi, M.; Pour, P.S.; Sichen, D. Experimental and Modeling Study on Reduction of Hematite Pellets with Hydrogen Gas. Metall. Mater. Trans. B 2017, 48, 1114-1122. [CrossRef]

14. Nuber, D.; Eichberger, H.; Rollinger, B. Circored Fine Ore Direct Reduction. Stahl Eisen 2006, 126, 4.

15. Jörgensen, C.; Thorngren, I. Thermodynamic Tables for Process Metallurgist; Almqvist och Wiksell: Stockholm, Sweden, 1969.

16. Kruck, O.; Crotogino, F.; Prelicz, R.; Rudolph, T. Overview on All Known Underground Storage Technologies for Hydrogen; Grant Agreement No.: 303417, Deliverable No. 3.1; Hydrogen Europe: Bruxelles, Belgium, 2013.

17. Mansson, L.; Marion, P. The LRC Concept and the Demonstration Plant-A New Approach to Commercial Gas Storage. In Proceedings of the IGU World Gas Conference, Tokyo, Japan, 1-5 June 2003.

18. Tengborg, P. Stora bergrum I Sverige LRC Gaslager I Halmstad. 2006. Available online: http://www.dftu.dk/ Faelles/Modereferater/St\%20bergrum\%20060228\%20Per\%20Tengborg.pdf (accessed on 1 March 2017).

19. Tengborg, P.; Johansson, J.; Durup, J.G. Storage of highly compressed gases in underground Lined Rock Caverns-More than 10 years of experience. In Proceedings of the World Tunnel Congress 2014-Tunnels for a better Life, Foz do Iguacu, Brazil, 9-15 May 2014.

20. WorldSteel Association. Steel Statistical Yearbook; WorldSteel Association: Brussel, Belgium, 2019.

21. Hutchinson, T.P. Profitable flat Products from Electric Arc Furnace Steel. Steel Times Int. 1980, $208,40$.

22. Ottmar, H.; Ameling, D. Über einige besondere Problemebei der Verarbeitung von Eisenschwamm im Hochleistungs- Lichbogenofen. In Internationaler Eisenhuttentechnischer Kongress; Düsseldorf: Sohnstraße 65, Düsseldorf, Germany, 1974.

23. Plöckinger, E.; Etterich, O. Electrostahlerzeugung; Verlag Stahleisen, M.B.H., Ed.; Düsseldorf: Sohnstraße 65, Düsseldorf, Germany, 1979.

24. HYBRIT-Fossil Free Steel. Summary of Findings from HYBRIT Pre-Feasibility Study 2016-HYBRIT Development $A B$; HYBRIT_Fossil Free Steel: Stockholm, Sweden, 2018. 